\title{
INVESTIGATION INTO HYDRIDE REORIENTATION IN DUMMY FUEL ROD CLADDING (Zr-1\% Nb) UNDER INTERNAL PRESSURE DURING TESTING SIMULATING SNF HANDLING AND ACCIDENTS WITH LIMITING CLADDING HEATING UP TO $410{ }^{\circ} \mathrm{C}$
}

\author{
G.P. Riedkina, T.P. Chernyayeva, V.M. Grytsyna, V.S. Krasnorutskyy, \\ I.A. Petelguzov, O.O. Slabospytska \\ "Nuclear Fuel Cycle" Science and Technology Establishment \\ National Science Center "Kharkov Institute of Physics and Technology”, Kharkiv, Ukraine \\ E-mail: gritsina@kipt.kharkov.ua
}

This paper presents the results of experimental investigations into hydride reorientation that (HRT) can occur in fuel rod claddings under conditions simulating normal and some accident SNF handling modes with limiting cladding heating up to $410{ }^{\circ} \mathrm{C}$. Dummy fuel rods with $\mathrm{Zr}-1 \% \mathrm{Nb}$ cladding with different hydrogen content under internal pressure (cold pressure under cladding of 3, 4, and $5 \mathrm{MPa}$ ) were subjected to testing with heating up to $410{ }^{\circ} \mathrm{C}$, holding at this temperature during $8 \mathrm{~h}$ and subsequent cooling. It was found that at a hydrogen concentration of $400 \mathrm{ppm}$, intensive hydride reorientation in the dummy fuel rod claddings during thermal test begins at a tangential stress of $\approx 55 \ldots 60 \mathrm{MPa}$ at $410^{\circ} \mathrm{C}$. As the hydrogen concentration decreases, the intensity of test impact on hydride reorientation decreases significantly. SNF thermal cycling and holding in DSFSF significantly increases hydride reorientation. In the claddings with a $400 \mathrm{ppm}$ hydrogen concentration subjected to 3 thermal cycles $180 \leftrightarrow 410^{\circ} \mathrm{C}$, almost complete hydride reorientation occurs. Mechanical testing of samples with different hydrogen content was conducted before and after the hydride reorientation test.

\section{INTRODUCTION}

One of the dangerous phenomena in fuel assembly handling is hydride reorientation. When heated in the process of drying, hydrides of tangential orientation, which is favorable in terms of its effect on the plasticity and which is set by the cladding tube manufacturing technology, can dissolve. Long-term dry storage of SFA fuel rods can result in formation of radial hydrides with orientations set by acting stresses. Hydride reorientation can lead to plasticity reduction in SFA zirconium claddings and promote their damage. In view of this dangerous phenomenon, large-scale, systematic and increasingly detailed investigations into the phenomena responsible for SFA zirconium cladding degradation, including hydride reorientation are being conducted in all countries, which have "dry" storage facilities, for which test methods are being developed and facilities are being established.

Currently, the technology for manufacturing cladding tubes determines their propensity towards formation of hydrides of a favorable tangential orientation (in terms of the effect of hydrides on cladding plasticity under operating stresses). Under stress, hydrides perpendicular to the tensile stress and parallel to the compressive stress are formed. Initial orientation of hydrides in zirconium fuel rod claddings changes when they are dissolved during heating, and hydrides of a different orientation set by the stress are formed during subsequent cooling. SNF handling and further long-term storage create the conditions which promote reorientation of hydrides from the favorable (tangential) orientation set by the processing - TO (Technology Orientation) and subsequent formation of hydrides of the unfavorable orientation set by the stress - SO (Stress Orientation) [5-7].

The main array of information on SNF behavior during dry storage relates to typical PWR $(14 \times 14$ PWR $-17 \times 17$ PWR $)$ and BWR $(8 \times 8$ BWR $-10 \times 10$ BWR $)$ fuel assemblies [8]. Considering their potential danger, hydride reorientation and hydrogen embrittlement of zirconium SFA components require systematic, routine and increasingly detailed examination [9].

\section{MATERIALS AND METHODS}

The test material was $\mathrm{Zr}-1 \% \mathrm{Nb}$ (E110) cladding tubes with an external diameter of $9.13 \mathrm{~mm}$ and a wall thickness of $0.68 \mathrm{~mm}$ in as received state (finish annealing at $580{ }^{\circ} \mathrm{C}, 3 \mathrm{~h}$ ) [8]. The tubes were used for cutting out $2.7 \mathrm{~mm}$ wide annular samples for the mechanical tests.

The samples were hydrogenated in the facility for saturation in hydrogen gas atmosphere ("dry" hydrogenation) at atmospheric pressure and at the temperature of $400{ }^{\circ} \mathrm{C}$ [10].

Hydride reorientation test is conducted in accordance with the NFC STE methodology on hydrogenated dummy fuel rods [10] under internal pressure of 3,4 , and $5 \mathrm{MPa}$ with $\mathrm{Zr}-1 \% \mathrm{Nb}$ alloy claddings with heating to $410^{\circ} \mathrm{C}$ (Fig. 1).

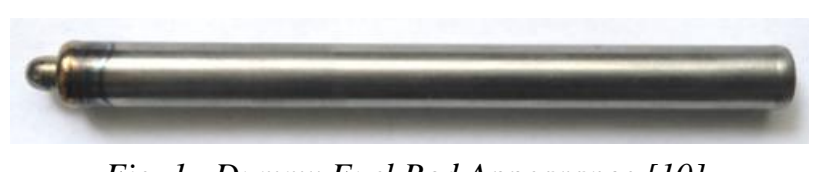

Fig. 1. Dummy Fuel Rod Appearance [10]

The temperature mode for the hydride reorientation test was selected based on the requirements for the maximum allowable SNF handling temperature used in 
different countries [12]. A cycle of tests was previously conducted with limiting heating up to $450{ }^{\circ} \mathrm{C}$, which is the maximum allowable temperature for WWER-1000 SFA handling and loading into the SS ZNPPP DSFSF [13].

In this study, the limiting temperature for SNF handling used in Hungary $\left(410{ }^{\circ} \mathrm{C}\right)$ was taken as the basis, based on the requirements for the maximum allowable handling temperature for WWER-440 SNF [12].

The temperature modes used during the hydride reorientation test are shown in Table 1 and Fig. 2.

Table 1

Temperature modes during hydride reorientation test

\begin{tabular}{|c|c|c|}
\hline $\begin{array}{l}\text { Pressure } \\
\text { under } \\
\text { cladding } \\
\left(P_{293}\right) \\
\mathrm{MPa}\end{array}$ & Mode & Test conditions \\
\hline $\begin{array}{l}3,4, \\
\text { and } 5\end{array}$ & Mode 1 & $\begin{array}{l}\text { Simulation of handling: heating at } \\
\text { the rate of } \sim 10{ }^{\circ} \mathrm{C} / \mathrm{min} \text { to } 410{ }^{\circ} \mathrm{C} \text {, } \\
\text { holding during } 8 \mathrm{~h} \text { and } \\
\text { subsequent cooling at the rate of } \\
2 \ldots 4^{\circ} \mathrm{C} / \mathrm{min}[12]\end{array}$ \\
\hline $\begin{array}{l}3,4, \\
\text { and } 5\end{array}$ & Mode 2 & $\begin{array}{l}\text { Simulation of handling and } \\
\text { accidents with } 3 \text { thermal cycles: } \\
\text { heating at the rate of } 10^{\circ} \mathrm{C} / \mathrm{min} \text {, } \\
\text { holding for } 3 \mathrm{~h} \text {, cooling at the rate } \\
\text { of } 2 \ldots 4^{\circ} \mathrm{C} / \mathrm{min} \text { to } 300^{\circ} \mathrm{C} \text { and } \\
\text { subsequent } 3 \text { thermal cycles } \\
410 \leftrightarrow 300{ }^{\circ} \mathrm{C} \text { with holding during } \\
1.4 \mathrm{~h} \text { at } 410^{\circ} \mathrm{C} \text { and } 1 \mathrm{~h} \text { at } 300^{\circ} \mathrm{C}\end{array}$ \\
\hline $\begin{array}{l}3,4, \\
\text { and } 5\end{array}$ & Mode 3 & $\begin{array}{l}\text { Simulation of handling and } \\
\text { accidents with } 3 \text { thermal cycles: } \\
\text { heating at the rate of } \sim 10^{\circ} \mathrm{C} / \mathrm{min} \text {, } \\
\text { holding for } 3 \mathrm{~h} \text {, cooling at the rate } \\
\text { of } 2 \ldots 4^{\circ} \mathrm{C} / \mathrm{min} \text { to } 300^{\circ} \mathrm{C} \text { and } \\
\text { subsequent } 3 \text { thermal cycles } \\
410 \leftrightarrow 180{ }^{\circ} \mathrm{C} \text { with holding during } \\
1.4 \mathrm{~h} \text { at } 410^{\circ} \mathrm{C} \text { and } 1 \mathrm{~h} \text { at } 180^{\circ} \mathrm{C}\end{array}$ \\
\hline
\end{tabular}

The tangential stress in the fuel rod cladding was calculated using the formula:

$$
\sigma_{\theta}=\frac{P_{293} D_{m i d}}{2 t} \cdot \frac{(T+273)}{293},
$$

where $P_{293}$ is internal gas pressure under cladding at room temperature, $\mathrm{MPa} ; D_{\text {mid }}$ - average cladding diameter, $\mathrm{mm} ; T_{\text {test }}-$ test temperature, ${ }^{\circ} \mathrm{C} ; t-$ wall thickness, mm.

Characteristics of the dummy fuel rods subjected to the hydride reorientation test, of which the samples for the metallographic studies and short-term mechanical tests were cut out are shown in Tables 2 and 3. The tables also show the tangential stress $\sigma_{\theta}$ in the dummy fuel rod claddings under pressure at $410{ }^{\circ} \mathrm{C}$ (simulated handling conditions with heating up to $410{ }^{\circ} \mathrm{C}$ ) and the stress at the temperature of the beginning of hydride precipitation for each specific hydrogen concentration [H].

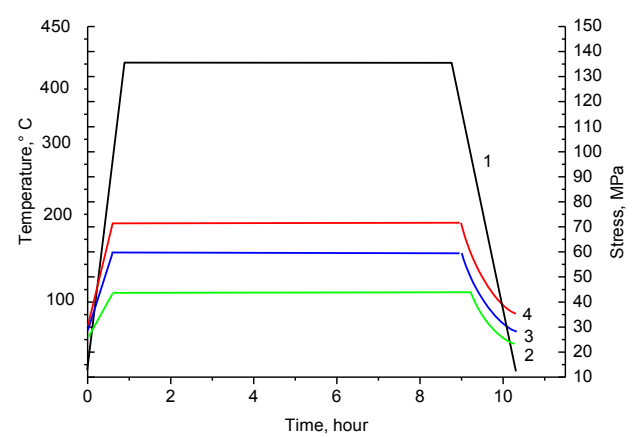

$a$

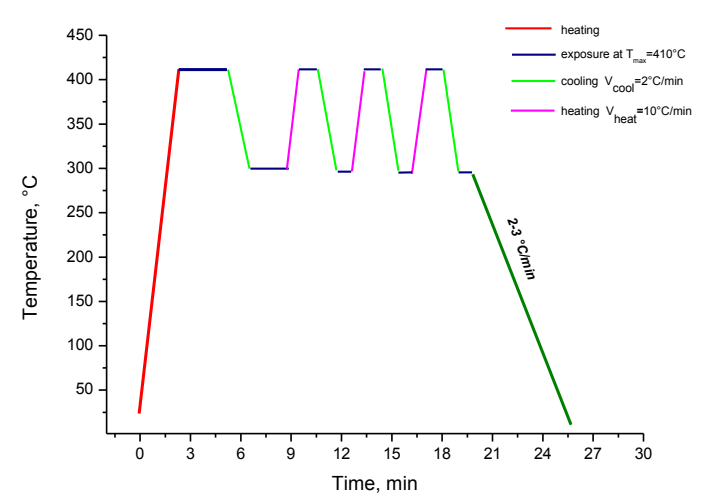

$b$

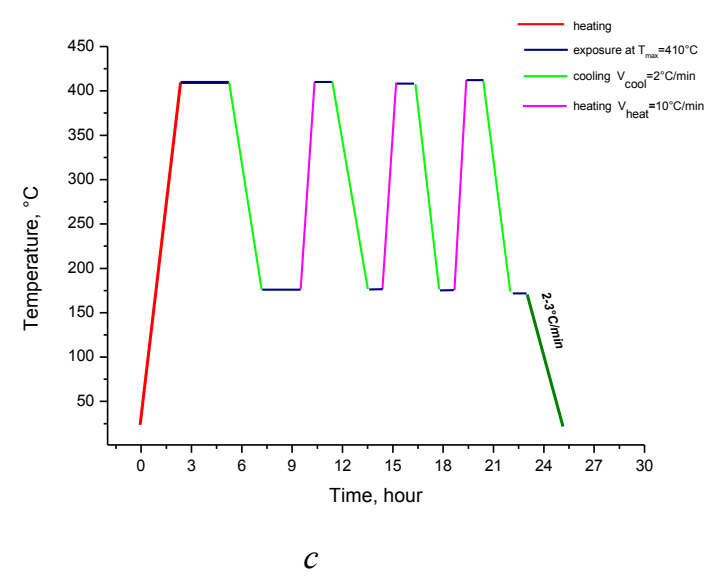

Fig. 2. Temperature conditions for dummy fuel rod hydride reorientation test in the mode simulating handling conditions with limiting heating up to $410^{\circ} \mathrm{C}$ (mode 1) (a)

and accidents with 3 thermal cycles $410 \leftrightarrow 300^{\circ} \mathrm{C}(\mathrm{b})$, and accidents with 3 thermal cycles $410 \leftrightarrow 180^{\circ} \mathrm{C}$ (c)

Table 2

Characteristics of dummy fuel rods for tests simulating handling operations with heating up to $410^{\circ} \mathrm{C}$

\begin{tabular}{|c|c|c|c|c|}
\hline $\begin{array}{c}\text { Dummy } \\
\text { No }\end{array}$ & $\begin{array}{c}{[\mathrm{H}],} \\
\mathrm{ppm}\end{array}$ & $\begin{array}{c}P_{293}, \\
\mathrm{MPa}\end{array}$ & $\begin{array}{c}\sigma_{\theta, \mathrm{TSSP}}, \\
\mathrm{MPa}\end{array}$ & $\begin{array}{c}\sigma_{\theta} \text { at } 410^{\circ} \mathrm{C}, \\
\mathrm{MPa}\end{array}$ \\
\hline 1 & 2 & 3 & 4 & 5 \\
\hline 1 & 104 & 3 & 35.2 & 43.5 \\
\hline 19 & 180 & 3 & 39.0 & 43.5 \\
\hline 14 & 200 & 3 & 39.8 & 43.5 \\
\hline
\end{tabular}


Continuation of Table 2

\begin{tabular}{|c|c|c|c|c|}
\hline 1 & 2 & 3 & 4 & 5 \\
\hline 26 & 328 & 3 & 44.1 & 43.5 \\
\hline 32 & 350 & 3 & 44.7 & 43.5 \\
\hline 36 & 400 & 3 & 46.1 & 43.5 \\
\hline 29 & 106 & 4 & 47.1 & 58 \\
\hline 20 & 170 & 4 & 51.4 & 58 \\
\hline 21 & 210 & 4 & 53.5 & 58 \\
\hline 27 & 300 & 4 & 57.7 & 58 \\
\hline 31 & 350 & 4 & 59.7 & 58 \\
\hline 35 & 420 & 4 & 62.2 & 58 \\
\hline 39 & 100 & 5 & 58.3 & 72.4 \\
\hline 13 & 204 & 5 & 66.5 & 72.4 \\
\hline 34 & 250 & 5 & 69.4 & 72.4 \\
\hline 30 & 310 & 5 & 72.6 & 72.4 \\
\hline 33 & 340 & 5 & 74.1 & 72.4 \\
\hline 24 & 410 & 5 & 77.3 & 72.4 \\
\hline
\end{tabular}

Table 3

Characteristics of dummy fuel rods for tests simulating handling conditions with heating up to $410^{\circ} \mathrm{C}$ and accidents with 3 thermal cycles

\begin{tabular}{|c|c|c|c|c|}
\hline $\begin{array}{c}\text { Dummy } \\
\text { No }\end{array}$ & $\begin{array}{l}\mathrm{H}], \\
\mathrm{ppm}\end{array}$ & $\begin{array}{l}P_{293}, \\
\mathrm{MPa}\end{array}$ & $\begin{array}{c}\sigma_{\theta, \text { TSSP }} \\
\mathrm{MPa}\end{array}$ & $\begin{array}{c}\sigma_{\theta} \text { at } 410^{\circ} \mathrm{C} \\
\mathrm{MPa}\end{array}$ \\
\hline 12 & 50 & 3 & 31.2 & 43.5 \\
\hline 16 & 300 & 3 & 43.2 & 43.5 \\
\hline 7 & 100 & 3 & 34.9 & 43.5 \\
\hline 5 & 200 & 3 & 39.8 & 43.5 \\
\hline 2 & 200 & 3 & 39.8 & 43.5 \\
\hline 4 & 280 & 3 & 42.6 & 43.5 \\
\hline 8 & 115 & 3 & 35.8 & 43.5 \\
\hline 11 & 65 & 3 & 32.5 & 43.5 \\
\hline 15 & 200 & 3 & 39.8 & 43.5 \\
\hline 32 & 300 & 4 & 57.7 & 58 \\
\hline 30 & 210 & 4 & 53.3 & 58 \\
\hline 37 & 150 & 4 & 50.15 & 58 \\
\hline 34 & 70 & 4 & 43.9 & 58 \\
\hline 67 & 298 & 4 & 57.6 & 58 \\
\hline 69 & 200 & 4 & 53.0 & 58 \\
\hline 3 & 100 & 5 & 58.2 & 72.4 \\
\hline 6 & 50 & 5 & 51.96 & 72.4 \\
\hline 10 & 120 & 5 & 60.2 & 72.4 \\
\hline 22 & 300 & 5 & 72.1 & 72.4 \\
\hline 23 & 200 & 5 & 66.3 & 72.4 \\
\hline 9 & 120 & 5 & 60.2 & 72.4 \\
\hline 17 & 150 & 5 & 62.7 & 72.4 \\
\hline 18 & 100 & 5 & 58.2 & 72.4 \\
\hline 25 & 300 & 5 & 72.1 & 72.4 \\
\hline 28 & 200 & 5 & 66.3 & 72.4 \\
\hline
\end{tabular}

\section{CHANGE OF HYDRIDE ORIENTATION IN DUMMY FUEL RODS DURING TESTS SIMULATING SNF HANDLING WITH LIMITING HEATING UP TO $410{ }^{\circ} \mathrm{C}$}

Dummy fuel rods $(\mathrm{Zr}-1 \% \mathrm{Nb})$ under the initial internal pressure $P_{293}=3,4$, and $5 \mathrm{MPa}$ were tested in the mode simulating SNF handling with limiting heating up to $410^{\circ} \mathrm{C}$.
Fig. 3 shows the change in hydride orientation in $\mathrm{Zr}-1 \% \mathrm{Nb}$ dummy fuel rod cladding with the initial internal pressure of $5 \mathrm{MPa}$ when tested in the mode simulating SFA handling with a maximum heating to $410{ }^{\circ} \mathrm{C}$.

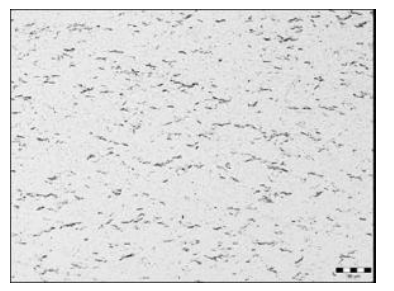

A1) $140 \mathrm{ppm}$, before HRT, $F_{\mathrm{n}} \approx 0.06$

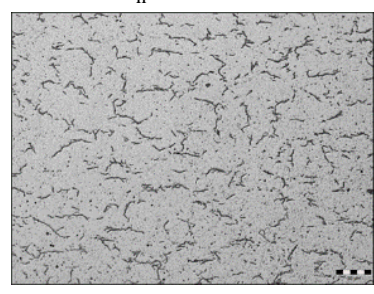

B1) $218 \mathrm{ppm}$, before HRT, $F_{\mathrm{n}} \approx 0.1$

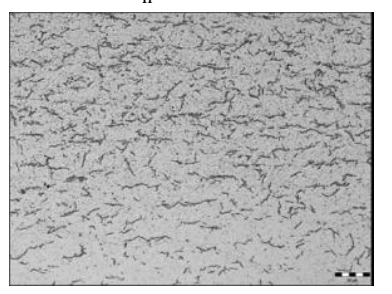

C1) $320 \mathrm{ppm}$, before HRT, $F_{\mathrm{n}} \approx 0.11$

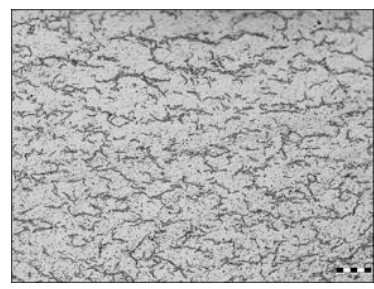

D1) $400 \mathrm{ppm}$, before HRT, $F_{\mathrm{n}} \approx 0.12$

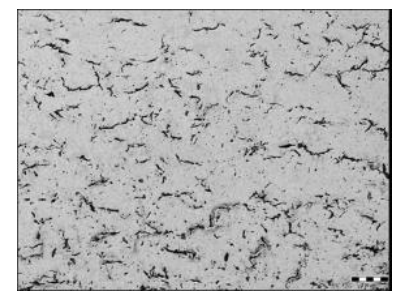

A2) $140 \mathrm{ppm}, P_{293}=5.0 \mathrm{MPa}$ $\sigma_{\theta}$ at $410{ }^{\circ} \mathrm{C}=72.4 \mathrm{MPa}, F_{\mathrm{n}} \approx 0.17$

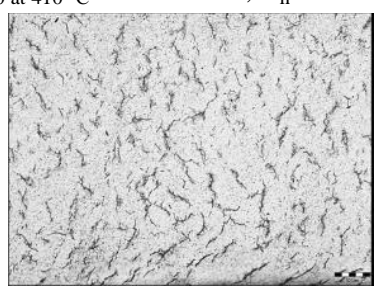

B2) $218 \mathrm{ppm}, P_{293}=5.0 \mathrm{MPa}$ $\sigma_{\theta}$ at $410^{\circ} \mathrm{C}=72.4 \mathrm{MPa}, F_{\mathrm{n}} \approx 0.64$

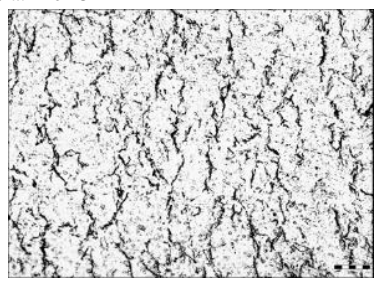

C2) $320 \mathrm{ppm}, P_{293}=5.0 \mathrm{MPa}$ $\sigma_{\theta}$ at $410^{\circ} \mathrm{C}=72.4 \mathrm{MPa}, F_{\mathrm{n}} \approx 0.79$

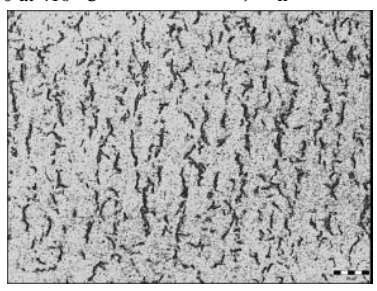

D2) $400 \mathrm{ppm}, P_{293}=5.0 \mathrm{MPa}$ $\sigma_{\theta}$ at $410{ }^{\circ} \mathrm{C}=72.4 \mathrm{MPa}, F_{\mathrm{n}} \approx 0.82$
Fig. 3. Hydride distribution in fuel rod dummy claddings before (on the left) and after their testing in the temperature mode simulating SNF handling with limiting cladding heating up to $410^{\circ} \mathrm{C}$. Initial internal pressure under cladding $P_{293}=5 \mathrm{MPa}($ mode 1$)$.

Cross-section. Reference: $50 \mu \mathrm{m}$

The data given in Fig.3 show that for the hydrogen concentrations in $\mathrm{Zr}-1 \% \mathrm{Nb}$ claddings of $218 \mathrm{ppm}$ and higher, testing of the dummy fuel rods under the pressure of $5 \mathrm{MPa}$ with heating up to $410{ }^{\circ} \mathrm{C}$ results in a significant hydride reorientation. The hydride orientation coefficient for the dummies with the hydrogen content of $400 \mathrm{ppm}$ is 0.82 .

Table 2 provides the results of all tests conducted in the mode simulating SFA handling in DSFSF with limiting heating of $410^{\circ} \mathrm{C}$. 
Table 4

Hydride orientation coefficients for $\mathrm{Zr}-1 \% \mathrm{Nb}$ dummy cladding with initial internal pressure $P_{293}=3,4$, and

$5 \mathrm{MPa}$ tested in the mode simulating SFA handling in DSFSF with limiting heating of $410{ }^{\circ} \mathrm{C}$

\begin{tabular}{|c|c|c|c|c|c|}
\hline $\begin{array}{l}P_{293} \\
\mathrm{MPa}\end{array}$ & $\begin{array}{l}{[\mathrm{H}],} \\
\mathrm{ppm}\end{array}$ & $\begin{array}{c}\sigma_{\theta, 410^{\circ} \mathrm{C}} \\
\mathrm{MPa}\end{array}$ & $\begin{array}{c}\sigma_{\theta, \text { TSSP }} \\
\mathrm{MPa}\end{array}$ & $\begin{array}{c}F_{0}, \\
\text { before } \\
\text { HRT }\end{array}$ & $\begin{array}{l}F_{\mathrm{n}}, \\
\text { after } \\
\text { HRT }\end{array}$ \\
\hline \multirow{4}{*}{3} & 120 & 43.45 & 36.10 & 0.06 & 0.09 \\
\hline & 190 & 43.45 & 39.36 & 0.08 & 0.28 \\
\hline & 286 & 43.45 & 42.81 & 0.08 & 0.38 \\
\hline & 400 & 43.45 & 46.12 & 0.12 & 0.68 \\
\hline \multirow{4}{*}{4} & 80 & 58.0 & 44.85 & 0.04 & 0.09 \\
\hline & 208 & 58.0 & 53.44 & 0.09 & 0.56 \\
\hline & 280 & 58.0 & 56.8212 & 0.1 & 0.67 \\
\hline & 400 & 58.0 & 61.49 & 0.12 & 0.78 \\
\hline \multirow{4}{*}{5} & 140 & 72.4 & 61.89 & 0.06 & 0.17 \\
\hline & 218 & 72.4 & 67.43 & 0.1 & 0.64 \\
\hline & 320 & 72.4 & 73.11 & 0.11 & 0.79 \\
\hline & 400 & 72.4 & 76.87 & 0.12 & 0.82 \\
\hline
\end{tabular}

According to the results of hydride reorientation tests of the dummy fuel rod claddings of $\mathrm{Zr}-1 \% \mathrm{Nb}$ in the mode simulating SFA handling in the DSFS with limiting heating to $410^{\circ} \mathrm{C}$ :

- no significant reorientation of hydrides occurs in the in the dummy fuel rod claddings with a hydrogen content of less than $200 \mathrm{ppm}$ (below the hydride solubility limit in $\mathrm{Zr}-1 \% \mathrm{Nb}$ at $410{ }^{\circ} \mathrm{C}-206 \mathrm{ppm}$ );

- at a hydrogen concentration above $200 \mathrm{ppm}$, $\mathrm{Zr}-1 \% \mathrm{Nb}$ claddings have a high tendency to hydride reorientation. With a hydrogen content above 200 ppm, the threshold stress before the beginning of intense hydride reorientation does not exceed $58 \mathrm{MPa}$

It should be noted that $\mathrm{Zr}-1 \% \mathrm{Nb}$ (E110) alloy claddings after four years of operation in WWER reactors $(\sim 45(\mathrm{MW} \cdot \mathrm{h}) / \mathrm{kgU})$, including fuel rods after operation at Ukrainian NPPs (SUNPP, ZNPP, RNPP, KhNPP) demonstrate insignificant hydrogenation, with a mass fraction of hydrogen of $\sim 50 \ldots 60 \mathrm{ppm}$ and not exceeding $80 \mathrm{ppm}$. The hydrides in the form of point and plate-like formations up to $\sim 80 \mu \mathrm{m}$ in size have a predominantly tangential orientation, which is favorable in terms of the mechanical properties of the cladding (Fig. 4) [14, 15]. At such a hydrogen concentration, no significant hydride reorientation occurs in the claddings under the conditions that simulate WFA handling operations with heating to $410{ }^{\circ} \mathrm{C}$ in DSFSF, and thus, no significant hydrogen embrittlement is expected.

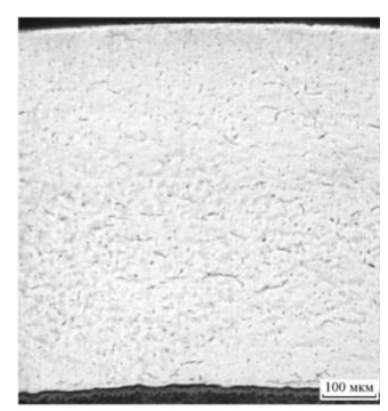

Fig. 4. Hydrides in $\mathrm{Zr-1} \% \mathrm{Nb}$ fuel rod claddings with fuel burn up of $70(\mathrm{MW} \cdot \mathrm{h}) / \mathrm{kgU}$ [14]

\section{HYDRIDE ORIENTATION IN DUMMY FUEL ROD CLADDING UNDER INTERNAL PRESSURE DURING TESTING SIMULATING HANDLING CONDITIONS AND ACCIDENTS WITH LIMITING HEATING UP TO $410{ }^{\circ} \mathrm{C}$}

Dummy fuel rods under pressure $\left(P_{293}=3,4\right.$, and $5 \mathrm{MPa}$ ) with hydrogenated $(50 \ldots 400 \mathrm{ppm}) \mathrm{Zr}-1 \% \mathrm{Nb}$ claddings were subjected to the hydride reorientation test in the modes simulating handling and accidents with 3 thermal cycles $410 \leftrightarrow 300$ and $410 \leftrightarrow 180{ }^{\circ} \mathrm{C}$.

Before the HRT, hydride orientation coefficient does not exceed 0.08 (Table 4). With a hydrogen concentration increase from 50 to $100 \mathrm{ppm}$ its value increases from 0.04 to 0.7 .

Fig. 5 provides the results of testing dummy fuel rod claddings under the pressure of 3 and $5 \mathrm{MPa}$ after the HRT, which simulated handling conditions and accidents with 3 thermal cycles $410 \leftrightarrow 300{ }^{\circ} \mathrm{C}$ : heating at the rate of $\sim 10^{\circ} \mathrm{C} / \mathrm{min}$ to $410^{\circ} \mathrm{C}$, holding for $3 \mathrm{~h} \rightarrow$ cooling at the rate of $2 \ldots 3{ }^{\circ} \mathrm{C} / \mathrm{min}$ to $300{ }^{\circ} \mathrm{C}$, holding for $3 \mathrm{~h}$ and 3 subsequent thermal cycles with holding for $1.5 \mathrm{~h}$ at $410^{\circ} \mathrm{C}$ and for 1 at $300^{\circ} \mathrm{C}$.

The data given in Fig. 6,a and in Table 6 show that for the hydrogen concentration of $100 \mathrm{ppm}$ in dummy fuel rod claddings under the pressure of $3 \mathrm{MPa}$ $\left(\sigma_{\mathrm{t}}\right.$ at $\left.410^{\circ} \mathrm{C}=43.5 \mathrm{MPa}\right)$, after the hydrogen reorientation test simulating handling conditions with a limiting heating up to $410^{\circ} \mathrm{C}$ and accidents with three $410 \leftrightarrow 300{ }^{\circ} \mathrm{C}$ thermal cycles, the hydrogen orientation coefficient equals 0.24 , and it significantly increases with further increasing pressure under the cladding (tangential stress). At a hydrogen concentration of $120 \mathrm{ppm}$ for all stresses during the HRT, the hydride orientation coefficient is above 0.5. At a hydrogen concentration of $300 \mathrm{ppm}$, significant reorientation of hydrides occurs for all stresses. After the HRT, the hydride orientation coefficient is 0.87 .

Fig. 6 demonstrates the results of testing dummy fuel rod claddings under internal pressure of 3 and $5 \mathrm{MPa}$ after the hydride reorientation test simulating handling conditions and accidents with three $410 \leftrightarrow 180{ }^{\circ} \mathrm{C}$ thermal cycles: heating to $410^{\circ} \mathrm{C}$ at the rate of $\sim 10^{\circ} \mathrm{C} / \mathrm{min}$, holding for $3 \mathrm{~h} \rightarrow$ cooling at the rate of $2 \ldots 4^{\circ} \mathrm{C} / \mathrm{min}$ to $300^{\circ} \mathrm{C}$, holding for $3 \mathrm{~h}$ and 3 subsequent thermal cycles with holding for $1.5 \mathrm{~h}$ at $410^{\circ} \mathrm{C}$ and for $1 \mathrm{~h}$ at $180{ }^{\circ} \mathrm{C}$. 


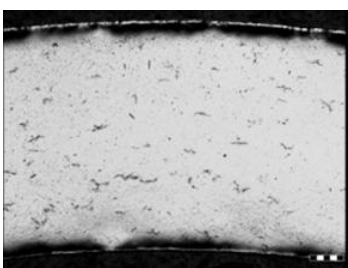

$a$

Sample No 12, $P_{293}=3.0 \mathrm{MPa}, 50 \mathrm{ppm}$, $F_{\mathrm{n}} \approx 0.12$

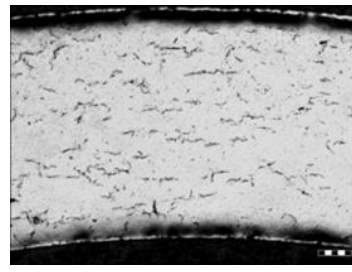

$c$

Sample No 7, $P_{293}=3.0 \mathrm{MPa}, 100 \mathrm{ppm}$, $F_{\mathrm{n}} \approx 0.24$

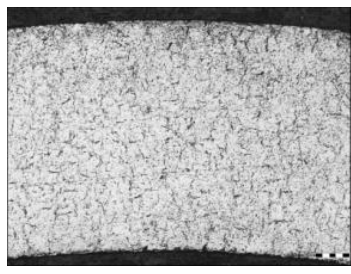
e

Sample No 17, $P_{293}=3.0 \mathrm{MPa}, 120 \mathrm{ppm}$, $F_{\mathrm{n}} \approx 0.53$

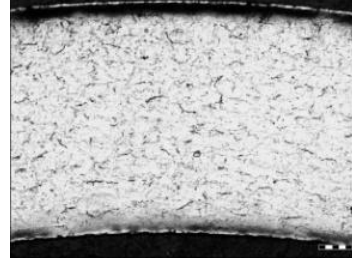

$g$

Sample No 5, $F_{\mathrm{n}} \approx 0.7$

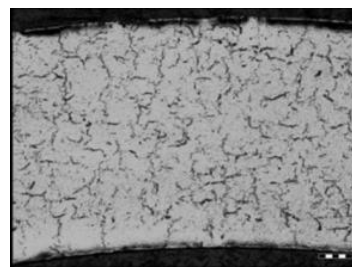
$i$

Sample No 16 $P_{293}=3.0 \mathrm{MPa}, 300 \mathrm{ppm}$, $F_{\mathrm{n}} \approx 0.87$ $P_{293}=3.0 \mathrm{MPa}, 200 \mathrm{ppm}$,

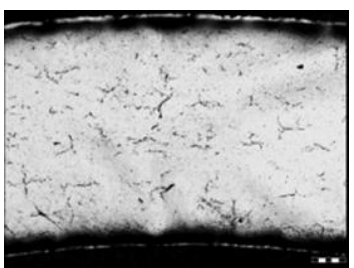

$b$

Sample No 6, $P_{293}=5.0 \mathrm{MPa}, 50 \mathrm{ppm}$ $F_{\mathrm{n}} \approx 0.23$

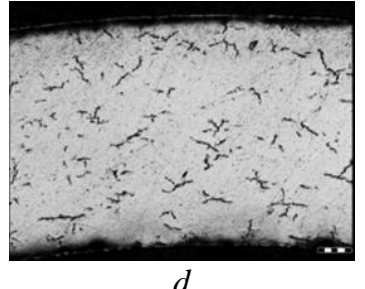

$d$

Sample No 3,

$P_{293}=5.0 \mathrm{MPa}, 100 \mathrm{ppm}$, $F_{\mathrm{n}} \approx 0.42$

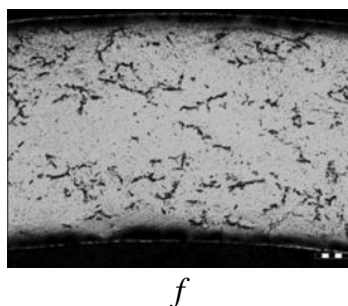

Sample No 10, $P_{293}=5.0 \mathrm{MPa}, 120 \mathrm{ppm}$, $F_{\mathrm{n}} \approx 0.53$

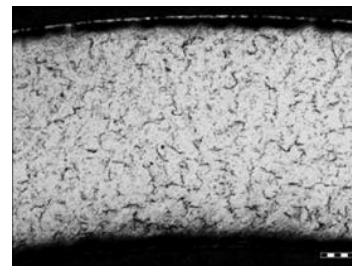

$h$

Sample No 23,

$P_{293}=5.0 \mathrm{MPa}, 200 \mathrm{ppm}$, $F_{\mathrm{n}} \approx 0.93$

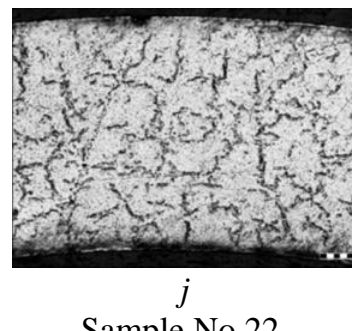

Sample No 22,

$P_{293}=5.0 \mathrm{MPa}, 300 \mathrm{ppm}$, $F_{\mathrm{n}} \approx 0.97$
Fig. 5. Results of testing dummy fuel rod claddings under internal pressure of 3 and $5 \mathrm{MPa}$ after HRT which simulated handling conditions with limiting heating of $410{ }^{\circ} \mathrm{C}$ and accidents with three $410 \leftrightarrow 300{ }^{\circ} \mathrm{C}$ thermal cycles

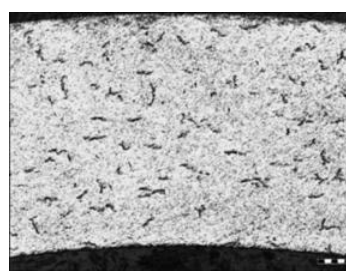

$a$

Sample No 11,

$P_{293}=3.0 \mathrm{MPa}, 65 \mathrm{ppm}$, $F_{\mathrm{n}} \approx 0.13$

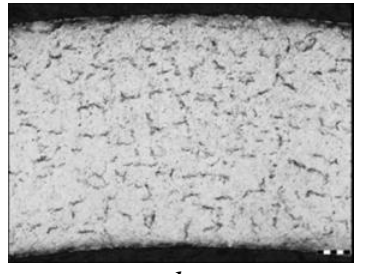

$b$

Sample No 8, $P_{293}=3.0 \mathrm{MPa}, 115 \mathrm{ppm}$, $F_{\mathrm{n}} \approx 0.44$

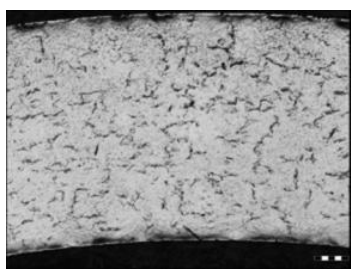

$c$

Sample No 4, $P_{293}=3.0 \mathrm{MPa}, 200 \mathrm{ppm}$ $F_{\mathrm{n}} \approx 0.87$

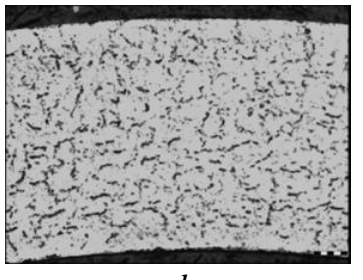

$d$

Sample No 2,

$P_{293}=3.0 \mathrm{MPa}, 300 \mathrm{ppm}$

$$
F_{\mathrm{n}} \approx 0.89
$$

Fig. 6. Results of testing dummy fuel rod claddings under internal pressure of 3 and 5 MPa after HRT which simulated handling conditions and accidents with three $410 \leftrightarrow 180{ }^{\circ} \mathrm{C}$ thermal cycles

As shown by the data in Fig. 6,a at a hydrogen concentration of $65 \mathrm{ppm}$ in the dummy fuel rod claddings under the pressure of $3 \mathrm{MPa}\left(\sigma_{\mathrm{t} a t} 410^{\circ} \mathrm{C}=\right.$ $=43.5 \mathrm{MPa}$ ), after the hydrogen reorientation test, which simulated handling conditions and accidents with three $410 \leftrightarrow 180^{\circ} \mathrm{C}$ thermal cycles, the hydrogen orientation coefficient changes insignificantly and equals 0.13 after the HRT.

At a hydrogen concentration of $100 \mathrm{ppm}$ and higher at all stresses after the HRT which simulated handling conditions with limiting heating up to $410{ }^{\circ} \mathrm{C}$ and accidents with three $410 \leftrightarrow 180^{\circ} \mathrm{C}$ thermal cycles, the hydrogen orientation coefficient increases significantly 
above 0.4 (see Fig. 6,b). With a hydrogen concentration increase to $300 \mathrm{ppm}$ during the HRT, the hydrogen orientation coefficient increases up to 0.97 (see Fig. $6, c)$. As is clear from the data obtained, at a hydrogen concentration above 100 ppm after all hydrogen reorientation tests, which simulated handling conditions and accidents with three $410 \leftrightarrow 180{ }^{\circ} \mathrm{C}$ thermal cycles, significant hydride reorientation is observed.

Tables 5 and 6 summarize the results of hydride reorientation tests in the modes simulating handling conditions and accidents with three $410 \leftrightarrow 300$ and $410 \leftrightarrow 180{ }^{\circ} \mathrm{C}$ thermal cycles, respectively.

Table 5

Hydride reorientation coefficients in $\mathrm{Zr}-1 \% \mathrm{Nb}$ dummy claddings under initial internal pressure $P_{293}=3,4$, and

$5 \mathrm{MPa}$, tested in the modes simulating SFA handling

in DSFS and accidents with three $410 \leftrightarrow 300{ }^{\circ} \mathrm{C}$ thermal cycles

\begin{tabular}{|c|c|c|c|c|c|}
\hline $\begin{array}{c}P_{293}, \\
\mathrm{MPa}\end{array}$ & $\begin{array}{c}{[\mathrm{H}],} \\
\mathrm{ppm}\end{array}$ & $\begin{array}{c}\sigma_{\theta, 410^{\circ} \mathrm{C},}, \\
\mathrm{MPa}\end{array}$ & $\begin{array}{c}\sigma_{\theta}, \mathrm{TSSP}, \\
\mathrm{MPa}\end{array}$ & $\begin{array}{c}F_{0}, \\
\text { before } \\
\text { HRT }\end{array}$ & $\begin{array}{c}F_{\text {n }}, \\
\text { after } \\
\text { HRT }\end{array}$ \\
\hline \multirow{4}{*}{3} & 50 & 43.5 & 31.17675 & 0.04 & 0.12 \\
\cline { 2 - 6 } & 100 & 43.5 & 34.95 & 0.04 & 0.24 \\
\cline { 2 - 6 } & 120 & 43.5 & 36.10 & - & 0.53 \\
\cline { 2 - 6 } & 200 & 43.5 & 39.77 & 0.06 & 0.7 \\
\cline { 2 - 6 } & 300 & 43.5 & 43.25 & 0.07 & 0.87 \\
\hline \multirow{4}{*}{4} & 50 & 58 & 41.57 & 0.04 & 0.14 \\
\cline { 2 - 6 } & 150 & 58 & 50.15 & 0.05 & 0.34 \\
\cline { 2 - 6 } & 200 & 58 & 53.02 & 0.06 & 0.7 \\
\cline { 2 - 6 } & 300 & 58 & 57.67 & 0.07 & 0.87 \\
\hline \multirow{4}{*}{5} & 50 & 72.4 & 51.96 & 0.04 & 0.23 \\
\cline { 2 - 6 } & 100 & 72.4 & 58.255 & 0.04 & 0.42 \\
\cline { 2 - 6 } & 120 & 72.4 & 60.17 & - & 0.53 \\
\cline { 2 - 6 } & 200 & 72.4 & 66.28 & 0.06 & 0.93 \\
\cline { 2 - 6 } & 300 & 72.4 & 72.09 & 0.08 & 0.97 \\
\hline
\end{tabular}

Table 6

Hydride reorientation coefficients in $\mathrm{Zr}-1 \% \mathrm{Nb}$ dummy claddings with initial internal pressure $P_{293}=3,4$, and $5 \mathrm{MPa}$, tested in the modes simulating SFA handling in DSFS and accidents with three $410 \leftrightarrow 180{ }^{\circ} \mathrm{C}$ thermal cycles

\begin{tabular}{|c|c|c|c|c|c|}
\hline $\begin{array}{c}P_{293}, \\
\mathrm{MPa}\end{array}$ & $\begin{array}{c}{[\mathrm{H}],} \\
\mathrm{ppm}\end{array}$ & $\begin{array}{c}\sigma_{\theta, 410}{ }^{\circ} \mathrm{C}, \\
\mathrm{MPa}\end{array}$ & $\begin{array}{c}\sigma_{\theta, \mathrm{TSSP}}, \\
\mathrm{MPa}\end{array}$ & $\begin{array}{c}F_{0}, \\
\text { before } \\
\text { HRT }\end{array}$ & $\begin{array}{c}F_{\text {n, }} \\
\text { after } \\
\text { HRT }\end{array}$ \\
\hline \multirow{4}{*}{3} & 65 & 43.5 & 32.51 & 0.04 & 0.13 \\
\cline { 2 - 6 } & 115 & 43.5 & 35.82 & 0.04 & 0.44 \\
\cline { 2 - 6 } & 200 & 43.5 & 39.77 & 0.06 & 0.87 \\
\cline { 2 - 6 } & 300 & 43.5 & 43.251 & 0.07 & 0.89 \\
\hline \multirow{4}{*}{4} & 50 & 58 & 41.5689 & 0.04 & 0.16 \\
\cline { 2 - 6 } & 150 & 58 & 50.1 & 0.05 & 0.42 \\
\cline { 2 - 6 } & 200 & 58 & 53.02 & 0.06 & 0.74 \\
\cline { 2 - 6 } & 300 & 58 & 57.66 & 0.07 & 0.89 \\
\hline \multirow{4}{*}{5} & 70 & 72.4 & 54.84 & 0.04 & 0.17 \\
\cline { 2 - 6 } & 120 & 72.4 & 60.17 & 0.04 & 0.61 \\
\cline { 2 - 6 } & 200 & 72.4 & 66.28 & - & 0.72 \\
\cline { 2 - 6 } & 300 & 72.4 & 72.09 & 0.06 & 0.89 \\
\hline
\end{tabular}

Figs. 7 and 8 show the dependences of the hydride orientation coefficient on the hydrogen concentration and stress at $410{ }^{\circ} \mathrm{C}$ in the dummy claddings after the
HRT with three thermal cycles $410 \leftrightarrow 300$ and $410 \leftrightarrow 180{ }^{\circ} \mathrm{C}$.

As seen from Figs. 7 and 8, in both cases, the threshold stress, at which hydride reorientation begins, decreases with increasing hydrogen concentration. In the dummy fuel rod claddings with a hydrogen concentration of $300 \mathrm{ppm}$, the threshold stress is very low $\left(\sigma_{\mathrm{t}, 410{ }^{\circ} \mathrm{C}} \approx 40 \ldots 45 \mathrm{MPa}\right)$. HRT with a tangential stress $\sigma_{\mathrm{t}, 410{ }^{\circ} \mathrm{C}}=72.4 \mathrm{MPa}$ results in a significant hydride reorientation in the claddings with a hydrogen concentration of $200 \ldots 300 \mathrm{ppm}$.

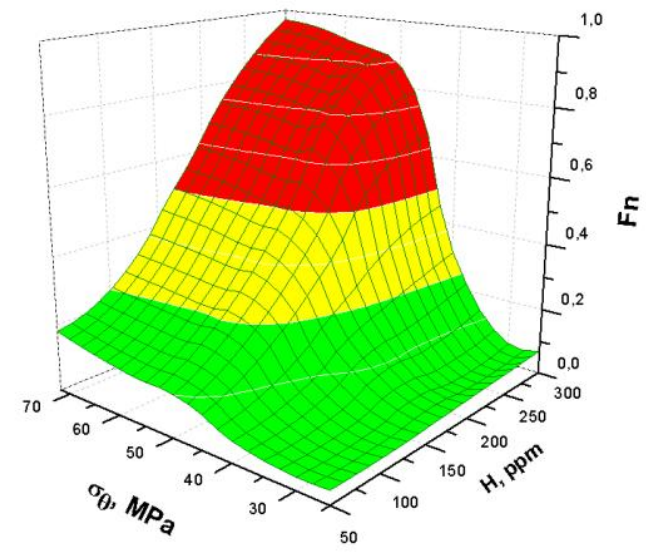

Fig. 7. Dependence of hydride orientation coefficient in internally pressurized dummy fuel rod claddings during testing in the mode simulating handling with limiting heating to $410^{\circ} \mathrm{C}$ and accidents with three $410 \leftrightarrow 300{ }^{\circ} \mathrm{C}$ thermal cycles on hydrogen concentration and tangential stress at $410^{\circ} \mathrm{C}$

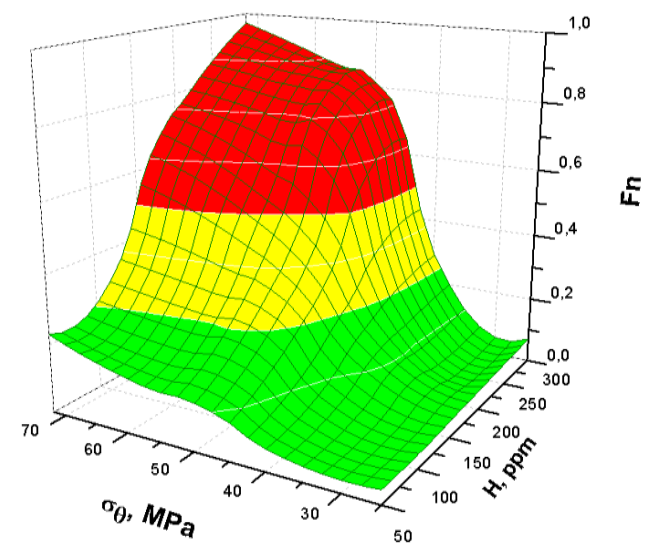

Fig. 8. Dependence of hydride orientation coefficient in internally pressurized dummy fuel rod claddings during testing in the mode simulating handling operations with limiting heating to $410^{\circ} \mathrm{C}$ and accident with three $410 \leftrightarrow 180^{\circ} \mathrm{C}$ thermal cycles on hydrogen concentration and tangential stress at $410^{\circ} \mathrm{C}$

As seen from Figs. 7 and 8, in both cases, the threshold stress at which hydride reorientation begins decreases with a hydrogen concentration increase. In the dummy fuel rod claddings with a hydrogen concentration of $300 \mathrm{ppm}$, the threshold stress is very low $\left(\sigma_{\mathrm{t}, 410^{\circ} \mathrm{C}} \approx 40 \ldots 45 \mathrm{MPa}\right)$. HRT with a tangential stress of $\sigma_{\mathrm{t}, 410^{\circ} \mathrm{C}}=72.4 \mathrm{MPa}$ results in a significant hydride reorientation in the claddings with a hydrogen concentration of $200 \ldots 300 \mathrm{ppm}$. 
Metallographic examinations demonstrated that:

- at a hydrogen concentration of $100 \mathrm{ppm}$, hydride reorientation test conducted in any of the modes used, has insignificant effect on hydride orientation in $\mathrm{Zr}-1 \% \mathrm{Nb}$ claddings;

- at a hydrogen concentration of $150 \mathrm{ppm}$ and higher, $\mathrm{Zr}-1 \% \mathrm{Nb}$ claddings have a very high propensity for hydride reorientation.

\section{EFFECT OF HYDROGEN AND HYDRIDE REORIENTATION ON THE MECHANICAL PROPERTIES OF Zr-1\% Nb CLADDINGS DURING TESTING SIMULATING HANDLING OPERATIONS AND ACCIDENTS WITH LIMITING HEATING UP TO $410{ }^{\circ} \mathrm{C}$}

A series of tests and studies to investigate the effect of hydrogen and hydride reorientation on the mechanical properties of $\mathrm{Zr}-1 \% \mathrm{Nb}$ claddings was carried out on annular samples with an outer diameter of $9.13 \mathrm{~mm}$, a wall thickness of $0.68 \mathrm{~mm}$ and a width of $2.7 \mathrm{~mm}$ :

- cut out from non-hydrogenated fuel rod claddings in as received state;

- cut out from hydrogenated segments of cladding tubes with a hydrogen content of $170 \ldots 400 \mathrm{ppm}$;

- cut out from dummy claddings after the hydride reorientation test simulating handling operations in the spent fuel pool and DSFS as well as handling and accidents with a limiting heating up to $410{ }^{\circ} \mathrm{C}$ (three $410 \leftrightarrow 300$ and $410 \leftrightarrow 180{ }^{\circ} \mathrm{C}$ thermal cycles). The test temperatures are 20,180 , and $350^{\circ} \mathrm{C}$. The strain rate is $5.7 \cdot 10^{-3} 1 / \mathrm{s}$.

Fig. 9 shows the dependence of the strength limit, yield stress and relative elongation of the samples cut out from the cladding tubes and hydrogenated tube segments at the mechanical test temperatures of 20 and $350{ }^{\circ} \mathrm{C}$.

At a temperature of $20^{\circ} \mathrm{C}$, non-hydrogenated cladding tubes have: $\sigma_{\mathrm{B}}=40.75 \mathrm{~kg}_{\mathrm{F}} / \mathrm{mm}^{2}, \quad \sigma_{0.2}=$ $37.5 \mathrm{~kg}_{\mathrm{F}} / \mathrm{mm}^{2}$, and $\delta=39.6 \%$.

With a hydrogen concentration increase to 170...400 ppm:

- the strength limit increases to $45.15 \ldots 48.3 \mathrm{~kg}_{\mathrm{F}} / \mathrm{mm}^{2}$;

- the yield stress increases to $42.2 \ldots 45.3 \mathrm{~kg}_{\mathrm{F}} / \mathrm{mm}^{2}$;

- the relative elongation decreases but does not go below $27 \%$.

At a temperature of $350{ }^{\circ} \mathrm{C}$, non-hydrogenated cladding tubes have: $\sigma_{\mathrm{B}}=17.75 \mathrm{~kg}_{\mathrm{F}} / \mathrm{mm}^{2}, \quad \sigma_{0.2}=$ $16.00 \mathrm{~kg}_{\mathrm{F}} / \mathrm{mm}^{2}$, and $\delta=38 \%$.

With a hydrogen concentration increase to 170...400 ppm:

- the strength limit increases to $19.1 \ldots 21.3 \mathrm{~kg}_{\mathrm{F}} / \mathrm{mm}^{2}$;

- the yield stress increases to $16.8 \ldots 19.5 \mathrm{~kg}_{\mathrm{F}} / \mathrm{mm}^{2}$;

- the relative elongation increases to $40.8 \ldots 44.2 \%$.

Thus, hydrogen (170...400 ppm) promotes strengthening of $\mathrm{Zr}-1 \% \mathrm{Nb}$ alloy at both 20 and $350{ }^{\circ} \mathrm{C}$; and at the same time reduces its plasticity at 20 and increases it at $350{ }^{\circ} \mathrm{C}$.

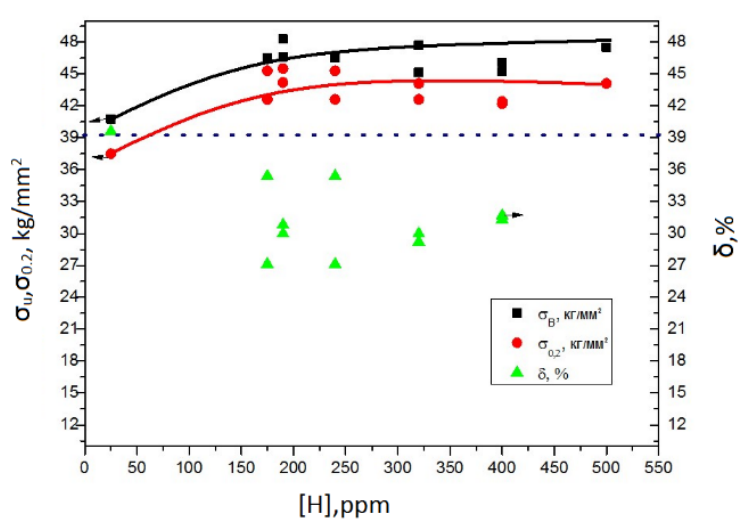

$a$

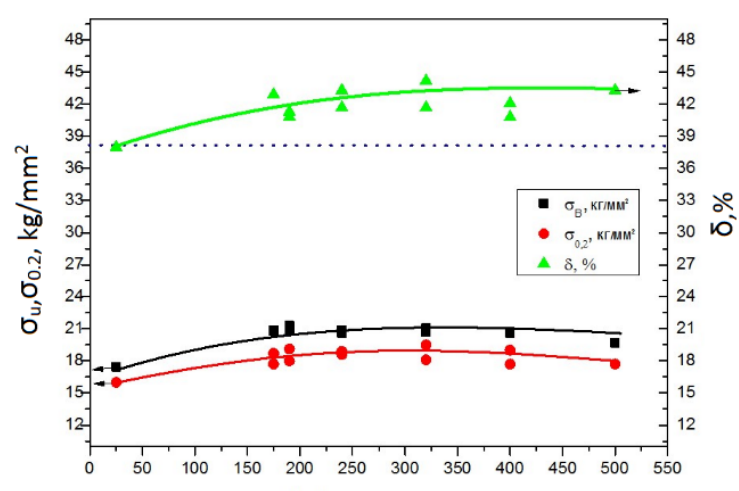

$[\mathrm{H}], \mathrm{ppm}$

$b$

Fig. 9. Strength limit, yield stress and relative elongation of $\mathrm{Zr}-1 \% \mathrm{Nb}$ (E110) cladding tubes versus hydrogen concentration. Mechanical test temperature: $20(a)$ and $350{ }^{\circ} \mathrm{C}(b)$

The results of the mechanical test on the samples cut from the hydrogenated $\mathrm{Zr}-1 \% \mathrm{Nb}$ dummy claddings subjected to the hydride reorientation test with three thermal cycles at 20,180 , and $350{ }^{\circ} \mathrm{C}$ are given in Figs. 10, 11, and 12, respectively. The dummy pressure at room temperature and the temperature mode during the three thermal cycles are shown in the Figs.
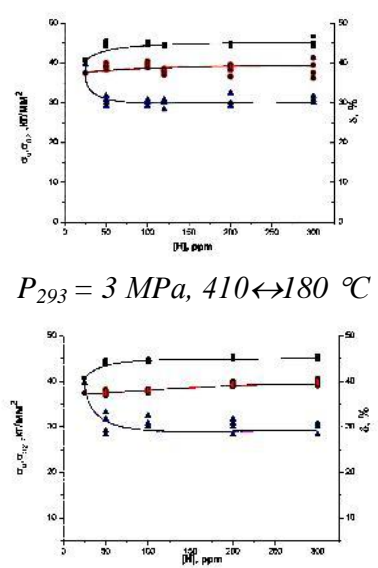

$P_{293}=3 \mathrm{MPa}, 410 \leftrightarrow 300{ }^{\circ} \mathrm{C}$
$P_{293}=3 \mathrm{MPa}, 410 \leftrightarrow 180^{\circ} \mathrm{C}$

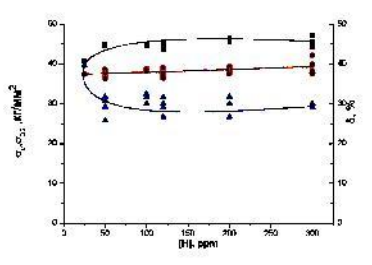

$P_{293}=5 \mathrm{MPa}, 410 \leftrightarrow 180{ }^{\circ} \mathrm{C}$

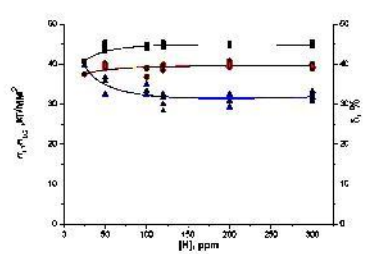

$P_{293}=5 \mathrm{MPa}, 410 \leftrightarrow 300{ }^{\circ} \mathrm{C}$
Fig. 10. Strength limit $\left(\sigma_{l} \square\right)$, yield stress $\left(\sigma_{0,2} \mathrm{O}\right)$ and relative elongation ( $\delta \% \Delta$ ) of $\mathrm{Zr}-1 \% \mathrm{Nb}$ dummy claddings versus hydrogen concentration. Mechanical test temperature: $20{ }^{\circ} \mathrm{C}$. Dummy pressure at room temperature and temperature mode during 3 thermal cycles are shown in the Fig. 
It follows from the data given in Fig. 10 that regardless of the previous hydride reorientation test mode (see Tables 5 and 6) hydrogen has the following effect on the mechanical properties of $\mathrm{Zr}-1 \% \mathrm{Nb}$ dummy claddings at the temperature of $20{ }^{\circ} \mathrm{C}$ :

- the strength limit increases from $(40.75 \pm 0.2) \mathrm{kg}_{\mathrm{F}} / \mathrm{mm}^{2}$ for non-hydrogenated samples to (45 \pm 3$) \mathrm{kg}_{\mathrm{F}} / \mathrm{mm}^{2}$ for samples cut out from dummy claddings with a hydrogen concentration of $100 . .300 \mathrm{ppm}$;

- the yield stress increases from $(37.5 \pm 0.2) \mathrm{kg}_{\mathrm{F}} / \mathrm{mm}^{2}$ for non-hydrogenated samples to (39...40) $\mathrm{kg}_{\mathrm{F}} / \mathrm{mm}^{2}$ for samples cut out from dummy claddings with a hydrogen concentration of 100...300 ppm;

- the relative elongation decreases from $(39.6 \pm 1) \%$ for non-hydrogenated samples to $(32 \pm 3) \%$ for samples cut out from dummy claddings with a hydrogen concentration of $100 \ldots 300 \mathrm{ppm}$.
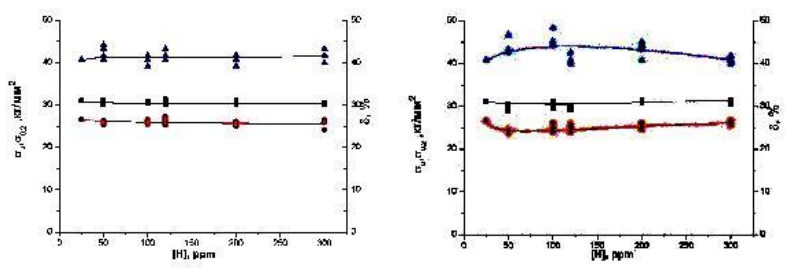

$P_{293}=3 \mathrm{MPa}, 410 \leftrightarrow 180{ }^{\circ} \mathrm{C}$
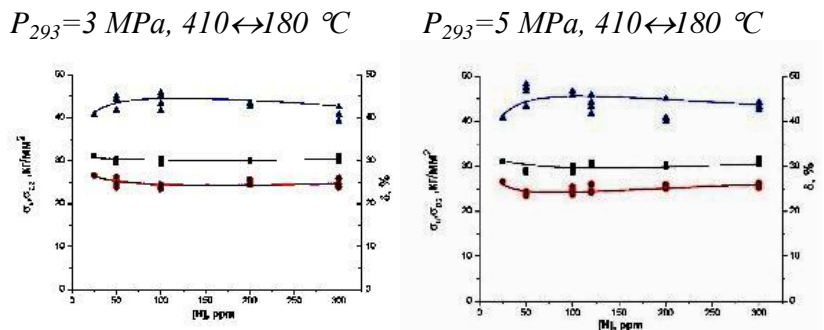

$P_{293}=3 \mathrm{MPa}, 410 \leftrightarrow 300{ }^{\circ} \mathrm{C}$

$$
P_{293}=5 \mathrm{MPa}, 410 \leftrightarrow 300{ }^{\circ} \mathrm{C}
$$

Fig. 11. Strength limit $\left(\sigma_{l, \square}\right)$, yield stress $\left(\sigma_{0,2} O\right)$ and relative elongation of dummy claddings ( $\delta \% \Delta)$

versus hydrogen concentration. Mechanical test

temperature: $180{ }^{\circ} \mathrm{C}$. Dummy pressure at room temperature and temperature mode of 3 thermal cycles are shown in the Fig.

It follows from the data provided in Fig. 11 that regardless of the mode of previous hydride reorientation tests (see Tables 5 and 6) hydrogen has the following effect on the mechanical properties of $\mathrm{Zr}-1 \% \mathrm{Nb}$ dummy claddings at the temperature of $180{ }^{\circ} \mathrm{C}$ :

- the strength limit practically does not depend on the hydrogen concentration. The strength limit values of samples tested at $180{ }^{\circ} \mathrm{C}$ range within $(32 \pm 2) \mathrm{kg}_{\mathrm{F}} / \mathrm{mm}^{2}$;

- the yield stress slightly changes in the area of small hydrogen concentrations (50..100 ppm); with further increase in the hydrogen content, the yield stress values either remain virtually unchanged or slightly increase; the yield stress values of the samples tested at $180{ }^{\circ} \mathrm{C}$ range within $(25 \pm 3) \mathrm{kg}_{\mathrm{F}} / \mathrm{mm}^{2}$;

- the dependence of the relative elongation of the samples on the hydrogen concentration reaches its maximum at the hydrogen concentration of
$50 \ldots 100 \mathrm{ppm}$. The relative elongation values of the samples tested at $180{ }^{\circ} \mathrm{C}$ range within $(45 \pm 4) \%$.

It follows from the data in Fig. 12 that regardless of the mode of previous hydride reorientation tests (see Tables 5 and 6), hydrogen has the following effect on the mechanical properties of $\mathrm{Zr}-1 \% \mathrm{Nb}$ dummy claddings at the temperature of $350{ }^{\circ} \mathrm{C}$ :

- the strength limit slightly increases with further increase in the hydrogen concentration. The strength limit values of the samples tested at $350{ }^{\circ} \mathrm{C}$ range within

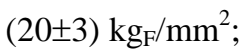

- the yield stress decreases insignificantly. The yield stress values of the samples tested at $350{ }^{\circ} \mathrm{C}$ range within $(16 \pm 3) \mathrm{kg}_{\mathrm{F}} / \mathrm{mm}^{2}$;

- the relative elongation of the dummy claddings increases from $(38.3 \pm 0.2)$ to $(42 \pm 2) \%$, while further increase in the hydrogen concentration up to $300 \mathrm{ppm}$ practically does not affect the cladding material plasticity.
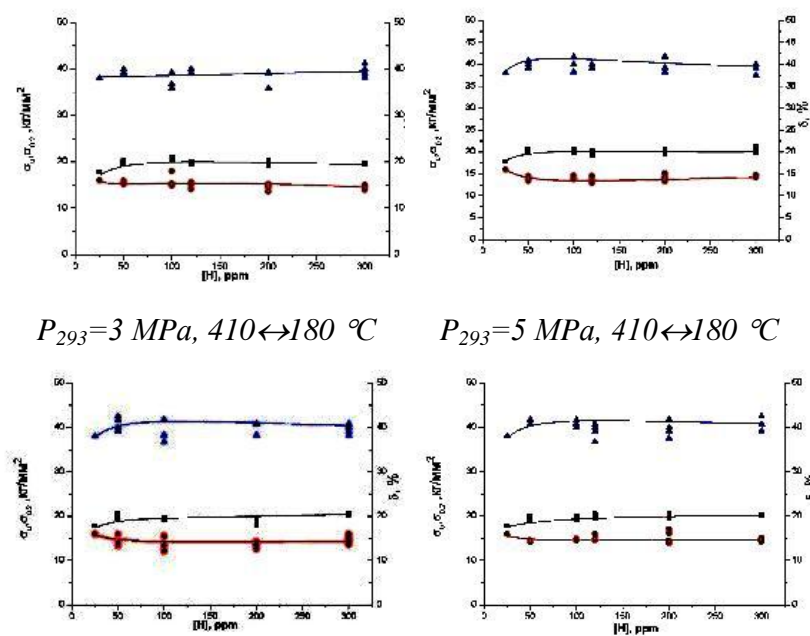

$P_{293}=3 \mathrm{MPa}, 410 \leftrightarrow 300{ }^{\circ} \mathrm{C}$

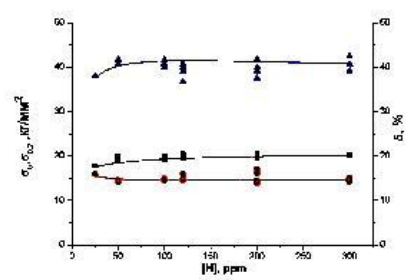

Fig. 12. Strength limit $\left(\sigma_{u} \square\right)$, yield stress $\left(\sigma_{0,2} O\right)$ and relative elongation of dummy claddings ( $\delta \% \Delta)$

versus hydrogen concentration. Mechanical test

temperature: $350{ }^{\circ} \mathrm{C}$. Dummy pressure at room temperature and temperature mode of 3 thermal cycles are shown in the Fig.

It is necessary to notice the high degree of reproducibility of the results obtained at each of the mechanical test temperatures.

According to the mechanical test results, changing tangential hydride orientation to radial hydride orientation occurring in the $\mathrm{Zr}-1 \% \mathrm{Nb}$ claddings during the HRT does not lead to their plasticity reduction.

\section{CONCLUSION}

1. $\mathrm{Zr}-1 \% \mathrm{Nb}$ cladding tubes were subjected to the HRT in the modes simulating SFA handling operations in DSFS with limiting heating to $410{ }^{\circ} \mathrm{C}$ that is accepted in Hungary for WWER-440 reactors and limiting accidents with three $410 \leftrightarrow 300{ }^{\circ} \mathrm{C}$ thermal cycles (mode 1 ) and $410 \leftrightarrow 180{ }^{\circ} \mathrm{C}$ (mode 2 ).

2. The test results obtained demonstrate that:

- at a hydrogen concentration of $50 \ldots 60 \mathrm{ppm}$ in $\mathrm{Zr}-1 \% \mathrm{Nb}$ claddings, the hydride orientation coefficient 
in the dummy claddings after the HRT conducted in the modes used in the study does not exceed $F_{\mathrm{n}} \leq 0.23$;

- at a hydrogen concentration of up to $100 \mathrm{ppm}$, the HRT conducted in any of the modes used in the study has little effect on the hydride orientation in $\mathrm{Zr}-1 \% \mathrm{Nb}$ claddings;

- at a hydrogen concentration of $150 \mathrm{ppm}$ and higher, $\mathrm{Zr}-1 \% \mathrm{Nb}$ have a very high propensity for hydride reorientation, $F_{\mathrm{n}} \geq 0.45$;

- at a hydrogen concentration of $200 \ldots 300 \mathrm{ppm}$ and higher in $\mathrm{Zr}-1 \% \mathrm{Nb}$ cladding at $\sigma_{\mathrm{t}} 410^{\circ} \mathrm{C} \geq 43.5 \mathrm{MPa}$, almost complete hydride reorientation occurs, $F_{\mathrm{n}} \geq 0.9$.

3 . According to the mechanical test results, changing tangential hydride orientation to radial hydride orientation occurring in the $\mathrm{Zr}-1 \% \mathrm{Nb}$ claddings during the HRT does not lead to their plasticity reduction.

4. The HRT with a limiting heating up to $410{ }^{\circ} \mathrm{C}$ compares in effective enesswith the HRT with a limiting heating up to $450{ }^{\circ} \mathrm{C}$ (currently accepted maximum temperature for SFA unloading from the spent fuel pool and placing it in the ZNPP DSFS).

The results of tests and investigations conducted show that SFA handling with limiting heating up to $410{ }^{\circ} \mathrm{C}$ and with $410 \leftrightarrow 300$ or $410 \leftrightarrow 180{ }^{\circ} \mathrm{C}$ limiting accidents can lead to significant hydride reorientation, which however will not affect their plasticity during further storage. In view of the potential danger of hydride reorientation and hydrogen embrittlement of zirconium components, systematic, routine and increasingly detailed examination of spent FAs is required.

\section{REFERENCES}

1. Iaea-rds-2/39. Nuclear power reactors in the world. IAEA reference data series. 2019, N 2, Vienna, $86 \mathrm{p}$.

2. F. Garzarolli, P. Rudling. Performance Evaluation of New Advanced $\mathrm{Zr}$ Alloys for PWRs/VVERs. ANT International, Mölnlycke, Sweden, October 2011, 205 p.

3. P. Rudling, R. Adamson, F. Garzarolli, B. Cox. $\mathrm{Zr}$ Alloy Corrosion and Hydrogen Pickup. ANT International, Mölnlycke, Sweden, December 2013, $82 \mathrm{p}$.

4. P. McConnell, B. Hanson, M. Lee, K. Sorenson. Extended dry storage of used nuclear fuel: technical issues: a USA perspective // Nuclear Engineering and Technology. 2011, v. 43, N 5, p. 405-412.
5. K.B. Colas, A.T. Motta, M.R. Daymond, M. Kerr, J.D. Almer // Journal of ASTM International. 2011, v. 8, N 1, p. ID JA1103033.

6. R.S. Daum, S. Majumdar, Y. Liu, M.C. Billone. Radial-hydride Embrittlement of High-burnup Zircaloy-4 Fuel Cladding // Journal of Nuclear Science and Technology. 2006, v. 43, N 9, p. 1054-1067.

7. M. Aomi, T. Baba, T. Miyashita, K. Kamimura, T. Yasuda, Y. Shinohara, T. Takeda. Evaluation of Hydride Reorientation Behavior and Mechanical Properties for High-burnup Fuel-Cladding Tubes in Interim Dry Storage // Journal of ASTM International. 2008, v. 5, N 9. Paper ID JAI101262.

8. M.C. Billone, T.A. Burtseva, Z. Han, Y.Y. Liu. Embrittlement and DBTT of High-burnup PWR Fuel Cladding Alloys. FCRD-UFD-2013-000401. Argonne National Laboratory, September 30, 2013, 65 p.

9. M.C. Billone, T.A. Burtseva, Z. Han, Y.Y. Liu. Effects of Multiple Drying Cycles on High-burnup PWR Cladding Alloys. CRD-UFD-2014-000052. Argonne National Laboratory, 2014, 82 p.

10. T.P. Chernyayeva, V.M. Grytsyna, V.S. Krasnorutskyy, A.P. Riedkina, I.A. Petelguzov, Ye.A. Slabospitskaya. Effects of fuel rod cladding temperature and stressed conditions on hydride reorientation // East European Scientific Journal (Warsaw, Poland). 2019, N 2(42), part 2, p. 55-67.

11. Materials performance during interim dry storage [capitalenergy.biz/?p=27126]

12. A.E. Novoselov, S.V. Pavlov, V.S. Polenok, D.V. Markov, V.A. Zhitelev, G.P. Kobylyansky, A.N. Kostyuchenko, I.N. Volkova. Condition of VVER fuel rod cladding after six years of operation // Physics and Chemistry of Materials Processing. 2009, N 2, p. 24-32.

13. https://www.npp.zp.ua/

14. R. Tang, X. Yang. Dissolution and precipitation behaviors of hydrides in N18, Zry-4 and M5 alloys // International Journal of Hydrogen Energy. 2009, v. 34, p. 726-727.

15. T.P. Chernyaeva, V.M. Grytsyna, V.S. Krasnorutskyy, A.P. Redkina, I.A. Petelguzov, Ye.A. Slabospitskaa. Effect of Fuel Rod Cladding Temperature and Stressed Conditions on Hydride Reorientation // Program and Abstracts: 18th International Symposium on "Zirconium in the Nuclear Industry". May 15-19, 2016. The Westin Hilton Head Island Resort and Spa, Hilton Heat Island, SC, USA. 2016, p. 76-77.

Статья поступила в редакциию 21.11.2019 2. 


\title{
ИССЛЕДОВАНИЕ ПЕРЕОРИЕНТАЦИИ ГИДРИДОВ В ОБОЛОЧКАХ (Zr-1\% Nb) МАКЕТОВ ТВЭЛОВ ПОД ВНУТРЕННИМ ДАВЛЕНИЕМ ПРИ ИСПЫТАНИИ, ИМИТИРУЮЩЕМ ПЕРЕГРУЗКИ ОЯТ И АВАРИИ С ПРЕДЕЛЬНЫМ НАГРЕВОМ ОБОЛОЧЕК ДО $410{ }^{\circ} \mathrm{C}$
}

\author{
А.П. Редкина, Т.П. Черняева, В.М. Грицина, В.С. Красноруцкий, \\ И.А. Петельгузов, Е.А. Слабоспицкая
}

\begin{abstract}
Представлены результаты экспериментальных исследований переориентации гидридов, которая может происходить в оболочках твэлов в условиях, имитирующих штатные и некоторые аварийные режимы обращения с ОЯТ и предельным нагреванием оболочек до $410^{\circ} \mathrm{C}$. Проведены испытания с нагревом макетов твэлов с оболочками из сплава $\mathrm{Zr}-1 \% \mathrm{Nb}$ и различным содержанием водорода под внутренним давлением (холодное давление под оболочкой 3,4 и $5 \mathrm{MПа)} \mathrm{до} \mathrm{температуры} 410{ }^{\circ} \mathrm{C}$, выдержкой при этой температуре 8 ч и последующим охлаждением. Установлено, что при содержании водорода $400 \mathrm{ppm}$ интенсивная переориентация гидридов в оболочках макетов твэлов при термических испытаниях начинается при тангенциальном напряжении $\approx 55 \ldots 60$ МПа и $410{ }^{\circ} \mathrm{C}$. С уменьшением содержания водорода интенсивность воздействия испытаний на переориентацию гидридов значительно снижается. Термоциклирование и выдержка ОЯТ в СХОЯТ приводят к усилению переориентации гидридов. В оболочках с концентрацией водорода $400 \mathrm{ppm}$, при испытаниях с трехкратным термоциклированием $180 \leftrightarrow 410{ }^{\circ} \mathrm{C}$ происходит практически полная переориентация гидридов. Проведены механические испытания образцов с различным содержанием водорода до и после испытаний.
\end{abstract}

\section{ДОСЛІДЖЕННЯ ПЕРЕОРІЄНТАЦІЇ ГІДРИДІВ В ОБОЛОНКАХ (Zr-1\% Nb) МАКЕТІВ ТВЕЛІВ ПІД ВНУТРІШНІМ ТИСКОМ ПРИ ВИПРОБУВАННІ, ЩО ІМІТУС ПЕРЕВАНТАЖЕННЯ ВЯП І АВАРІЇ 3 ГРАНИЧНИМ НАГРІВАННЯМ ОБОЛОНОК ДО $410{ }^{\circ} \mathrm{C}$}

\section{Г.П. Редкіна, Т.П. Чернясва, В.М. Грицина, В.С. Красноруцький, І.А. Петельгузов, О.О. Слабоспицька}

Представлено результати експериментальних досліджень переорієнтації гідридів, яка може мати місце в оболонках твелів в умовах, що імітують штатні і деякі аварійні режими поводження з ВЯП і граничним нагріванням оболонок до $410^{\circ} \mathrm{C}$. Проведено випробування з нагріванням макетів твелів 3 оболонками зі сплаву $\mathrm{Zr}-1 \% \mathrm{Nb}$ з різним вмістом водню під внутрішнім тиском (холодний тиск під оболонкою 3,4 і $5 \mathrm{MПа)}$ до температури $410{ }^{\circ} \mathrm{C}$, витримкою при цій температурі 8 год і наступним охолодженням. Встановлено, що при вмісті водню $400 \mathrm{ppm}$ інтенсивна переорієнтація гідридів в оболонках макетів твелів при термічних випробуваннях починається при тангенціальній напрузі $\approx 55 \ldots 60$ МПа при $410{ }^{\circ} \mathrm{C}$. Зі зменшенням вмісту водню інтенсивність впливу випробувань на переорієнтацію гідридів значно знижується. Термоциклування та витримка ВЯП у ССВЯП призводять до значного посилення переорієнтації гідридів. В оболонках 3 концентрацією водню $400 \mathrm{ppm}$, при випробуваннях 3 трикратним термоциклуванням $180 \leftrightarrow 410^{\circ} \mathrm{C}$ відбувається практично повна переорієнтація гідридів. Проведено механічні випробування зразків з різним вмістом водню до і після випробувань. 